\title{
firIISGUC.ORG
}

"İȘ, GÜC̣" ENDÜSTRi iLIȘKiLERi VE INSAN KAYNAKLARI DERGisi

"IS, GUC" INDUSTRIAL RELATIONS AND HUMAN RESOURCES JOURNAL

\section{Örgütsel Destek, Örgütsel Bağl1lık ve İşten Ayrılma Eğilimi İlişkisi: Havalimanı Yer Hizmetleri İşletmelerine Yönelik Bir Araştırma}

\author{
The Relationship among Organizational Support, \\ Organizational Commitment and Turnover Intention: \\ A Research in Ground Handling Business
}

Mahmut DEMIR

Muğla Üniversitesi

Ocak/January 2012, Cilt/Vol: 14, Say1/Num:1, Page: 47-64

ISSN: 1303-2860, DOI: 10.4026/1303-2860.2012.194.X

Makalenin on-line kopyasına erişmek için:

http://www.isguc.org/?p=article\&id=476\&vol=14\&num=1\&year=2012

To reach the on-line copy of article:

http://www.isguc.org/?p=article\&id=476\&vol=14\&num=1\&year=2012

Makale İçin İletişim/Correspondence to: 
(C) 2000- 2012

“İşGüç" Endüstri İlişkileri ve İnsan Kaynakları Dergisi

"İşGüç" Industrial Relations and Human Resources Journal

\author{
Ocak/January 2012, Cilt/Vol: 14, Say1/Num: 1 \\ ISSN: 1303-2860, DOI: 10.4026/1303-2860.2012.194.x
}

\section{Editör/Editor-in-Chief \\ Aşkın Keser (Uludă̆ University)}

Editör Yardimcıları/Co-Editors

K.Ahmet Sevimli (Uludağ University)

Gözde Yilmaz (Marmara University)

Uygulama/Design

Yusuf Budak (Kocaeli Universtiy)

\author{
Yayın Kurulu / Editorial Board \\ Dr. Erdem Cam (ÇASGEM) \\ Dr. Zerrin Furat (Uludă̆ University) \\ Doç. Dr. Aşkın Keser (Uludağ University) \\ Prof. Dr. Ahmet Selamoğlu (Kocaeli University) \\ Yrd. Doç. Dr. Ahmet Sevimli (Uludăg University) \\ Doç. Dr. Abdulkadir Şenkal (Kocaeli University) \\ Doç. Dr. Gözde Yilmaz (Marmara University) \\ Dr. Memet Zencirkıran (Uludă̆ University)
}

Uluslararası Danışma Kurulu / International Advisory Board Prof. Dr. Ronald Burke (York University - CA)

Assoc. Prof. Dr. Glenn Dawes (James Cook University - AU)

Prof. Dr. Jan Dul (Erasmus University - NL)

Prof. Dr. Alev Efendioğlu (University of San Francisco - USA)

Prof. Dr. Adrian Furnham (University College London - UK)

Prof. Dr. Alan Geare (University of Otago - NZ)

Prof. Dr. Ricky Griffin (TAMU-Texas AEM University - USA)

Assoc. Prof. Dr. Diana Lipinskiene (Kaunos University - LT)

Prof. Dr. George Manning (Northern Kentucky University - USA)

Prof. Dr. William L. Murray (University of San Francisco - USA)

Prof. Dr. Mustafa Özbilgin (Brunel University - UK)

Assoc. Prof. Dr. Owen Stanley (James Cook University - AU)

Prof. Dr. Işık Urla Zeytinoğlu (McMaster University - CA)

\section{Ulusal Danışma Kurulu / National Advisory Board}

Prof. Dr. Yusuf Alper (Uludağ University)

Prof. Dr. Veysel Bozkurt (İstanbul University)

Prof. Dr. Toker Dereli (Işık University)

Prof. Dr. Nihat Erdoğmuş (Şehir University)

Doç. Dr. Mustafa Kurt (Yalova University)

Prof. Dr. Ahmet Makal (Ankara University)

Prof. Dr. Süleyman Özdemir (İstanbul University)

Prof. Dr. Ahmet Selamoğlu (Kocaeli University)

Prof. Dr. Nadir Sŭ̆ur (Anadolu University)

Prof. Dr. Nursel Telman (Maltepe University)

Prof. Dr. Cavide Uyargil (İstanbul University)

Prof. Dr. Engin Yildirum (Constitutional Court of Turkey)

Doç. Dr. Arzu Wasti (Sabancı University)

Dergide yayınlanan yazılardaki görüşler ve bu konudaki sorumluluk yazarlarına aittir.

Yayınlanan eserlerde yer alan tüm içerik kaynak gösterilmeden kullanılamaz.

All the opinions written in articles are under responsibilities of the outhors.

The published contents in the articles cannot be used without being cited. 


\title{
Örgütsel Destek, Örgütsel Bağlılık ve İşten Ayrılma Eğilimi İlişkisi: Havalimanı Yer Hizmetleri İşletmelerine Yönelik Bir Araştırma
}

\author{
The Relationship among Organizational Support, Organizational \\ Commitment and Turnover Intention: A Research in Ground \\ Handling Business
}

Mahmut DEMIR

Muğla Üniversitesi

\begin{abstract}
Özet
Bu çalışmanın amacı, havalimanı yer hizmetleri işletmelerinde örgütsel destek (OD), örgütsel bağlllık (OB) ve işten ayrılma eğilimi (İAE) arasındaki ilişkiyi araştırmaktır. Öncelikle konuyla ilgili bir literatür taraması yapılmıştır. Buradan elde edilen bilgilerle araştırma modeli oluşturulmuş ve buna göre bir anket geliştirilmiştir. Yüzyüze görü̧sme tekniğgi kullanılarak toplam 282 katılımcıya bir anket uygulanmıştır. Elde edilen veriler SPSS ve LISREL istatistik programları ile analiz edilerek açıklayıcı faktör analizi (AFA) ile verilerin yapısal ve yakınsak geçerliliği yapılmıştır. Daha sonra $O D, O B$ ve İAE arasındaki ilişkiyi belirlemek amacıyla oluşturulan hipotezlerin ölçülmesi için yapısal eşitlik modelinde doğrulayıcı faktör analizi (DFA) gerçekleştirilmiştir. OD faktörleri ile $O B$ faktörleri arasında pozitif yönlü bir ilişki tespit edilirken İAE ile negatif yönlü bir ilişkinin varliğl ortaya konulmuştur. Diğer yandan OB faktörleri ile İAE arasında negatif yönlü güçlü bir ilişki olduğu saptanmıştır. Sonuçta oluşturulan tüm hipotezler kabul edilmiştir.
\end{abstract}

Anahtar Sözcükkler: Örgütsel destek, Örgütsel bağlllık, İşten ayrllma eğilimi, Yer hizmetleri işletmeleri.

\begin{abstract}
The purpose of this study was to investigate the relationship among organizational support, organizational commitment and turnover intention in ground handling enterprises. Previously a literature review was conducted for research model and then questionnaire was developed from the studies in the literature. Data were collected by researchers in face-to-face interviews with 282 employees and were analyzed with SPSS and LISREL statistical programs. Structural and convergent validity of the data have revealed with the explanatory factor analysis. And then, it was tested using a confirmatory factor analysis to determine the relationship among organizational support, organizational commitment and turnover intention in structural equation modelling. It was found to be a positive relationship between organizational support factors and organizational commitment factors while a negative relationship between organizational support factors and turnover intention. On the other hand, it was found to be a negative relationship between organizational commitment factors and turnover intention. As a result, all hypotheses have been adopted.
\end{abstract}

Keywords: Organizational support, Organizational commitment, Turnover intention, Ground handling business 


\section{Giriş}

Havacılık sektöründe A, B ve C grubu çalışma ruhsatlarıyla faaliyet gösteren yer hizmetleri işletmeleri de en az havayolu işletmeleri kadar önem taşımaktadır. Kurumsal kimliğe sahip bu tür işletmelerde nitelikli işgörenlere gereksinim olduğu gibi onları örgütsel hedefler doğrultusunda etkin ve verimli bir şekilde yönetmek de gerekir. $\mathrm{Bu}$ nedenle işgörenlerin temini ve seçimi kadar işletmede tutulmasında da yönetsel kararların etkin bir şekilde alınması örgüte değer kazandırabilmektedir. Yer hizmetleri işletmelerinde işgörenlerin yetkinliklerinin diğer hizmet işletmelerine göre daha fazla olması örgütsel faaliyetler açısından bir avantaj olarak değerlendirilmektedir. Bu tür işletmelerde sağlanan olanakların algılanması kişilere göre farklı olsa da, işgörenler üzerinde yarattığ1 etki düzeyi aynı zamanda yönetimin becerisini de ortaya koymaktadır. Hatta yönetsel uygulamaların, sunulan maddi ve manevi olanaklardan daha etkili olduğu yönünde araştırma sonuçları da bulunmaktadır (Van Knippenberg ve Sleebos, 2006; Rhoades ve Eisenberger, 2002; Meyer ve Smith, 2000; Van Scotter, 2000). İsgörenlerin işe güdülenmelerinin bireysel ve örgütsel düzeydeki etkileri, yöneticilerin örgütsel davranışlarında daha fazla özen göstermelerini gerekli kılmaktadır. Bununla birlikte, işgörenlere ekonomik ve sosyal olanaklarin sunularak örgütsel bağllıkklarının sağlanması, işletmede tutulmasında etkili olurken işten ayrılma eğiliminin de azalmasına etki edebilmektedir.

$\mathrm{Bu}$ çalışmanın amacı havalimanı içinde faaliyet gösteren yer hizmetleri işletmelerinde sağlanan örgütsel desteğin işgörenlerin çalıştıkları işletmeye bağlılıkları ve işten ayrılma eğilimi ile olan ilişkisini analiz etmektir. $\mathrm{Bu}$ tür işletmelerde diğer sektör işletmelerinden daha fazla sorumluluk taş1yan işgörenlerin en küçük hataları can ve mal kaybına neden olabileceği gibi çalıştıkları işletmelerin bulundukları yer itibariyle kişisel ve ülke güvenliği açısından da oldukça büyük risk taşıması birtakım yetkinliklere sahip olmasını gerektirmektedir. Daha nite- lik işgörenlerin olduğu düşünülen bu tür işletmelerde işgörenlere sağlanan örgütsel desteğe rağmen örgütsel bağlilık oluşmakta mıdır? Ya da bağlılık oluşsa bile ișten ayrılma eğilimini ne şekilde etkilenmektedir? Bu kapsamda $\mathrm{OD}, \mathrm{OB}$ ve İAE faktörlerinin birbiriyle ilişkisinin ortaya konulmasına yönelik olan bu çalışma havalimanlarında faaliyet gösteren yer hizmetleri işletmeleri için ayrıca önem taşımaktadır. Yer hizmetleri işletmelerinin seçilmesindeki temel amaç ise, işgören niteliklerinin yüksekliği, verilerin kolay toplanabilme olanağı, turizm sektörü içinde yıl boyunca faaliyet gösteren işletmelerin olması, işletmelerin birden fazla havalimanında faaliyet gösteren kurumsal bir kimliğe sahip olması ve bu tür işletmelerde belirlenen konunun daha önce araştırılmamış olmasıdir.

Çalışmada öncelikle, kavramsal olarak OD konusuna yer verilecek olup daha sonra OB konusu Meyer ve Allen'in devam bağl1lığ1 (DEVB), duygusal bağlılık (DUYB) ve normatif bağlılık (NORB) boyutları şeklinde değerlendirdiği kapsamda incelenecektir. Üçüncü aşamada yer hizmetleri işletmelerinde bu iki konunun İAE ile olan ilişkisi üzerine yapılandırılmış alan araştırması sonuçları analiz edilecektir. Elde edilen bulgular yer hizmetleri işletmeleri açısından olduğu kadar genel olarak turizm sektörü açısından da değerlendirilecektir. Çünkü turizm sektörünün genel yapısı gereği, işgören devir oranının yüksek olması (Tütüncü ve Demir, 2003) zaman ve maliyet açısından işletmeleri olumsuz etkilemektedir. Dolay1sıyla işten ayrılma eğiliminin işgörenlere sağlanan destek ve oluşan bağlılık ilişkisinden çıkabilecek olumlu sonuçlar işletmeler, işgörenler ve müşteriler açısından önemli katkılar yaratabilecektir.

\section{2.Örgütsel Destek}

Örgütlerde işgörenlerin uygulamalarını etkin bir şekilde gerçekleştirebilmeleri için isteklilik, zaman unsuru, sağlanan yetkinlik, örgütsel destek, insan kaynakları yönetimi politika ve prosedürleri gibi faktörler önem 
taşımaktadır (Bredin ve Söderlund, 2007:816). İşgörenlerin iş süreçlerinde en uygun kararları vermeleri ve olası hatalarının engellenmesi için örgütsel düzeyde sürekli ve sistematik olarak destek almaları (Whittaker ve Marchington, 2003:246) görev, yetki ve sorumlulukları ile ilgili üstlenecekleri yeni rolleri yürütebilmelerinde bilgi ve becerilerinin artmasinı (Armstrong, 2006:97) ve örgüte olan bağlılıklarını sağlayabilmektedir.

İşgörenlerin etkin ve verimli bir şekilde çalışabilmesi için öncelikle kendilerini güvende hissetmeleri ve örgütün bir parçası olarak görmeleri gerekir (Demir, 2010). Bu nedenle yöneticiler, işgörenleri örgüt içindeki görevlerine odaklandırmaya çalışarak yönetsel becerilerini ortaya koymaktadır (Eisenberger ve diğ., 1990:51). İşgörenlerin yönetim tarafından değer verildiğini algılaması ve çeşitli olanaklar sunulmasını fark etmesi, örgüt içinde çalışma yaşamı kalitesinin de yükselmesini sağlamaktadır (Demir, 2010). Bu durum aynı zamanda işgörenlere örgüt tarafından verilen desteğin bir göstergesi olarak işe güdülenmesinde olumlu katkılar sağlayabilmektedir

Örgütsel destek, işgörenlerin örgüt tarafından rahat bir çalışma ortamı yaratılarak (Eisenberger ve diğ., 2002:566; Wayne ve diğ., 2002:590), huzur ve mutluluklarınin (Fuller ve diğ., 2003:789), iş güveninin sağlanması (Eisenberger ve diğ., 1990:52) sonucunda örgütsel bağlılı̆̆ın arttırılması (Shore ve Wayne, 1993:774) ve işten ayrılma eğiliminin azaltılmasını (Lew, 2009:75; Wayne ve diğ., 1997:92) içermektedir. Destekleyici bir örgüt, işgörenlerin beklentilerini önemseyerek (Shore ve Tetrick, 1991:637) onlara değer vermelidir. Çünkü yüksek örgütsel destek, işgörenlerin daha etkili çalışma davranışlarını ortaya çıkarır (Özdevecioğlu, 2003:116).

Örgütsel destek ile ilişkilendirilen örgütsel davranış çalışmalarda değişkenler arasında farklı ilişkilerin olduğu ortaya konulmaktadır. Ferris, Brown ve Heller (2009), örgütsel destek ile örgütsel sapma arasında negatif yönlü bir ilişkinin olduğunu ve sonuçta işten ayrılma eğiminin arttığını öne sürmektedir. Susskind, Kacmar ve Borchgrevink, (2007) restoran hizmetlerinin geliştirilmesinde işgörenlerin birbirine destek unsurunun etkisini ortaya koymak amacıyla 271 kişi üzerinde yapmış olduğu araştırmasında yönetici desteği ile işgören desteği faktörlerin arasındaki pozitif yönlü ilişkinin müşteri doyumuna da olumlu yansıdığını belirtmektedir. Turizm işletmelerinde yönetsel destek aynı zamanda etkin bir liderliğin sağlamış olduğu olumlu davranışlarla işgörenlerin iş stresinin düşmesine, ișe devamsızlığın ve işten ayrılma eğilimin azalmasında, buna karşın iş doyumu ve örgütsel bağlılığının artmasında etkin bir rol oynamaktadır (Yang 2010; Cho ve Johanson, 2008; Erkutlu ve Chafra, 2006).

OD faktörünün $O B$ ve İAE faktörleri ile ilişkilerinin analiz edilmesi amacıyla oluşturulan hipotezler aşağıda yer aldığı gibi 4 grupta toplanarak incelenmiştir. Hipotezlerin ölçüm sonuçlarına araştırma bölümünde yer verilmiştir.

H1: Algılanan örgütsel destek ile devam bağlılık düzeyi arasında anlamlı bir ilişki vardir.

H2: Alg1lanan örgütsel destek ile duygusal bağlılık düzeyi arasında anlamlı bir ilişki vardir.

H3: Algılanan örgütsel destek ile normatif bağlılık düzeyi arasında anlamlı bir ilişki vardir.

H4: Algılanan örgütsel destek ile işgörenlerin işten ayrılma eğilimi arasında anlamlı bir ilişki vardır.

\section{3.Örgütsel Bağlılık}

Genel olarak işgörenlerin bir örgüte olan ilgisi ve ait olma duygusunu taşıyan OB (Payne ve Huffman, 2005:159; Valentine ve diğ., 2002:351; Hunt ve di $\breve{g}$., 1989:81), bireyin üyesi olduğu örgütle özdeşleşmesinin ve buna katılımının bir sonucu olarak değerlendirilmektedir. Mowday, Steers ve Porter'da (1979) OB'yi, örgütsel amaç ve değerlere güçlü bir şekilde inanma, onları benimseme, 
daha fazla çaba harcayarak örgüt üyeliğini sürdürme isteği olarak belirlerken, konuyu tutumsal ve davranışsal olmak üzere iki boyutta ele almışlardır. Bu yaklaşıma göre bağlılık, bireylerin örgütle özdeşleştiklerinde ve bu yönde çaba gösterdiklerinde görülmektedir (Paulin ve diğ., 2006:908; Kondratuk ve diğ., 2004:334; Schwepker, 2001:41; Clugston, 2000).

DeCotiis ve Summers (1987) örgütsel amaçların ve değerlerin içselleştirilmesi ile bu doğrultuda rol bağlılığını temel aldıkları OB'nin iki boyutlu bir yapı olduğunu öngörmüşlerdir. Buna karşın, Allen ve Meyer (1990) ise OB'yi, işgörenlerin örgütle ilişkisine göre oluşan ve örgüte ait olma duygusunu sağlayan bir davranış olarak üç boyutta incelemiş ve devam bağl1lı̆̆ı, duygusal bağlılık ve normatif bağlılık şeklinde sınıflandırmişlardır (Meyer ve diğ., 2002:21; Meyer ve Allen, 1991:62).

İşgörenlerin örgütten ayrılmaları durumunda oluşabilecek ekonomik kayıpların yaşamlarını etkileme derecesini göz önünde bulundurarak zorunlu olarak örgütte çalışmaya devam etmeleri (Meyer ve diğ., 1993:539) olarak ifade edilen DEVB, işten ayrilma durumunda katlanılacak maliyetleri, olumsuzlukları ya da örgütte kalmanın getirilerini dikkate alarak işe devam etmeyi öngörmektedir. Öyle ki, işgörenin örgüte yaptığı katkıların artması ve iş seçeneklerinin azalması DEVB'yi arttırırken (Meyer ve Allen, 1991:72) iş seçeneğinin fazla olması ise azaltmaktadır (Meyer ve Allen, 1997). İşgörenlerin örgütte çalıştığı süre içerisinde harcadığı emek, zaman ve çaba ile sahip olduğu statü, para gibi ekonomik ve sosyal kazanımlarını ișten ayrılmasıyla birlikte kaybedeceği düşüncesiyle zorunluluktan oluşan DEVB (Obeng ve Ugboro, 2003:87), işten ayrılmanın getireceği maliyetlerin farkında olunması anlamını taşımaktadır (Chen ve Francesco, 2003:8). DEVB, örgüt içi ilişkilerin, emeklilik yatırımları, iş deneyimleri gibi devredilemeyen kazanılmıs personel hakları nedeniyle İAE'yi güçleştirmekte (Ugboro ve Obeng, 2000), yüksek maliyetlerin oluşması örgüt üyeliğinin sürdürülmesine neden olmaktadır (Lamsa ve Savolanien, 2000:36; Somers ve Birnbaum, 2000:353).

DUYB, bireyin örgütle özdeşleşme ve etkileşim halinde, kendi istek ve tercihleriyle örgütün bir üyesi olması nedeniyle yaşamış olduğu duygusal durumu ifade etmektedir (Allen ve Meyer, 1990:2). İşgörenlerin DUYB, büyük ölçüde yaşanan iş deneyimleri sonucunda gelişmesi (Meyer ve Allen, 1991:82) ve onların örgütle bütünleşmesini yansitırken (Chen ve Francesco, 2003:501), aynı zamanda örgütte kalma eğiliminin artmasını sağlamaktadır (Huselid ve Nancy, 1991:380). Bu durum işgörenler için örgütün bir parçası olarak büyük bir anlam ve önem taşımaktadır. DUYB genel olarak, işgörenin amaçları ile örgüt arasındaki uyumun bir göstergesi olarak (Camp, 1992) işgörenin örgütle bütünleşmesini, kendisini örgüt içinde tanımlayabilirliğini ve örgütsel amaçlara katılımını ortaya koymaktadır (Meyer ve Allen, 1991). Güçlü DUYB, işgörenlerin İAE'yi azaltarak örgütsel hedef ve değerleri kabullenmesi anlamını taşımaktadır.

NORB, örgüt üyeliğinin sürdürülmesinde işgörenlerin vicdani yükümlülük duygusu içinde örgütte kalmaya yönelik algılanan zorunluluğu ifade etmektedir (Meyer ve Smith, 2000:320). Bu tür bağlllıkta işgörenlerin yaptıklarının doğru ve ahlaki olduğuna inanmalar1 (Obeng ve Ugboro, 2003:57) ve örgütün içinde kendilerine sağlanmış olan statü ve iş doyumundan farklı olarak, örgütte kalmanın ahlaki bakımdan önemli olduğunu ortaya koymaktadır (Meyer ve Allen, 1991:66). Yüksek NORB'ye sahip işgörenler, kendilerini örgüte karşı manevi borçlu ve zorunlu hissettikleri için örgütte çalışmayı kendisi için bir görev olarak görmektedir. Bu nedenle işgörenler, örgütte kalmanın doğru bir karar ya da davranış olduğu düşüncesiyle örgüt üyeliğini sürdürmektedir.

Örgütsel bağılılığın iş doyumunun sonucunda daha kolay sağlandığını ortaya koyan turizm sektöründe yapılmış çalışmalar (Namasivayam ve Zhao, 2007; Øgaarda ve diğ., 2008) işgörenlerin başarısında örgütsel kay- 
naklı faktörlerin daha etkili olduğunu öne sürmektedir. İşgörenlerin işe devamsızlık sonunun örgütsel bağlılıkla ilişkili olduğu, aynı şekilde işten ayrılma eğiliminin de örgütsel bağlılığ sağlanamamış kişilerde daha yüksek olduğu görülmektedir. Yönetsel destek işgörenlerin örgüte olan bağlllıklarını artmasinı olumlu yönde etkilerken, bunun sonucunda işletmeye üretim, maliyet ve zaman açısından işgören davranışlarının olası olumsuz etkilerinin önlenmesinde önemli rol oynamaktadır (O'Neill vd., 2009; Cho ve Johanson, 2008). Turizm işletmeleri açısından işgörenlerin örgüte olan bağlılıkları diğer sektör işletmelerinden daha fazla önemli bir durum yaratmaktadir.

Literatür taramasında elde edilen bilgiler çerçevesinde çalışmanın amacına yönelik olarak oluşturulan hipotezler araştırma bölümünde test edilerek yorumlanmaktadır. OB faktörlerinin İAE ile olan ilişkilerini ölçmeye yönelik oluşturulan hipotezleri aşağıdaki şekilde ifade etmek mümkündür.

H5: İşgörenlerin devam bağlllık düzeyi ile işten ayrılma eğilimi arasında anlamlı bir ilişki vardır.

H6: İşgörenlerin duygusal bağlılık düzeyi ile işten ayrılma eğilimi arasında anlamlı bir ilişki vardır.

H7: İşgörenlerin normatif bağlılık düzeyi ile işten ayrılma eğilimi arasında anlamlı bir ilişki vardır.

Örgütsel destek işgören başarısı üzerinde olumlu etkiler yaratarak iş çıtılarına katkı sağlamaktadır. İşgörenlerin algıladıkları destek örgüte ait olma duygusunun oluşmasına ve yaptığ 1 işi benimseyerek daha etkin bir şekilde üretim ve hizmet sürecine katılmasını motive etmektedir (Øgaarda ve diğ., 2008; Namasivayam ve Zhao, 2007; Susskind ve diğ., 2007). İş yaşamında doyuma ulaşan işgörenlerin sosyal yaşaminda da mutlu olması işte kalma eğilimin artmasına neden olurken, işe devamsızlık azalmakta, örgütsel sapma davranışı görülmemekte, çalışma ortamında kalitenin yükselmesine etki etmekte ve buna bağlı olarak örgüte olan bağll1ık art- maktadır. Örgütsel bağılığın artması, işgörenin işletmenin bir parçası olarak aktif sorumluluk almasına ve diğer çalışan ve müşteri memnuniyetinin artmasına olanak sağlamaktadır (Ferris ve diğ., 2009; Cho ve Johanson, 2008; Tütüncü ve Küçükusta, 2007).

\section{Havalimanı Yer Hizmetleri İşletmele- rinde Bir Araştırma}

\subsection{Araştırma Yöntemi}

$\mathrm{Bu}$ araştırma Eisenberger, Fasolo ve Davis-LaMastro (1990)'un OD ile Meyer ve Allen (1991)'in OB konusunda yapılmış çalışmaları baz alınarak oluşturulan bir model üzerine kurulmuştur. Bu çalışmalardan elde bilgiler çerçevesinde bir anket oluşturulmuştur. Eisenberger, Fasolo ve Davis-LaMastro (1990)'un OD ölçeğinden yararlanılmasının temel nedeni, araştırmacıların yaptığı çalışmanın örgütsel bağlılık ile ilişkisinin analizi yapılmış ve soru ifadeleri bu çalışmaya uygun özellikte olmasıdır. Geçerlilik ve güvenilirlik analizinin yapılmış ve oldukça yüksek düzeyde gerçekleşmiş olması da bir başka etkendir $(p<, 001$ ve $a=0,97)$. Ankette yer alan değişkenlerden OD1: özerklik, OD2; kişisel gelişim, OD3; teşvikler ve OD4; sosyal güvence olarak OD dişsal faktörünü oluşturmaktadır. OB içsel faktörü ise DEVB, DUYB ve NORB'den oluşmaktadır. Meyer ve Allen (1991)'in ölçeği oldukça geniş bir kullanım alana sahip ve genel olarak kabul görmüş bir ölçektir. Geçerlilik ve güvenilirlik analizinin yapılmış olması ve bu çalışmaya uygunluğu nedeniyle tercih edilmiştir. DEVB1: zorunluluktan dolayı devam etme, DEVB2: ekonomik çıkarlar nedeniyle devam etme ve DEVB3: daha iyi seçeneklerin olmamasından dolay1 devam etme, DUYB1: aitlik duygusu hissetme, DUYB2: kişisel olarak bağlanma ve DUYB3: mutlu olma, NORB1: vicdani sorumluluk, NORB2: etik değerler ve NORB3: sadakat duygusu, şeklinde öngörülen değişkenleri ifade etmektedir. İAE değişkenleri ise, İAE1: "gelecekte de bu işte çalışacağıma inaniyorum" ve İAE2: "daha iyi şartlarda başka bir iş bulduğumda ayrılırım" şeklinde 
ifade edilmiştir. Anket çalışması havalimanı yer hizmetleri işletmelerinde işgörenlerle yüzyüze gerçekleştirilmiştir. Ankette katılımcıların demografik özelliklerine yönelik olmak üzere 6 adet kapalı uçlu soru, Likert tipi ölçekte 33 adet bağımsız ve 2 adet bağımlı değişken sorusu olmak üzere toplam 41 adet soru yer almaktadır. Likert ölçeğine göre hazırlanan ve ters (reverse) olarak ifade edilen sorular döndürülerek analiz edilmiştir. Örgütsel destek ölçeğinde yer alan sorulardan 7 adedi ve örgütsel bağlllık ölçeğinde yer alan soruların 6 adedi çalışmanın genel yapısını (DFA aşamasında) bozması nedeniyle kapsam dişında tutulmuştur. AFA'da normal sonuçlar veren bu değişkenler DFA'da uyum endekslerinin sağlanması amacıyla kapsam dışında tutulmuştur. Bu çalışmanın verileri Dalaman ve Bodrum-Milas Havalimanlarında 2010 yılı Mart-Eylül döneminde elde edilmiştir.

\subsection{Araştırmanın Bulguları}

Araştırmada tanımlayıcı ve çıkarımsal istatistiksel analiz olarak sonuçlar iki bölümde değerlendirilmiştir. Bu kapsamda öncelikle katılımcıların demografik özelliklerine ilişkin bulguların sayısal ve yüzdesel dağılım sonuçları verilmektedir. İkinci aşamada gü-

\section{Tablo 1}

Demografik özelliklere ilişkin sayısal ve yüzdesel dağılım tablosu

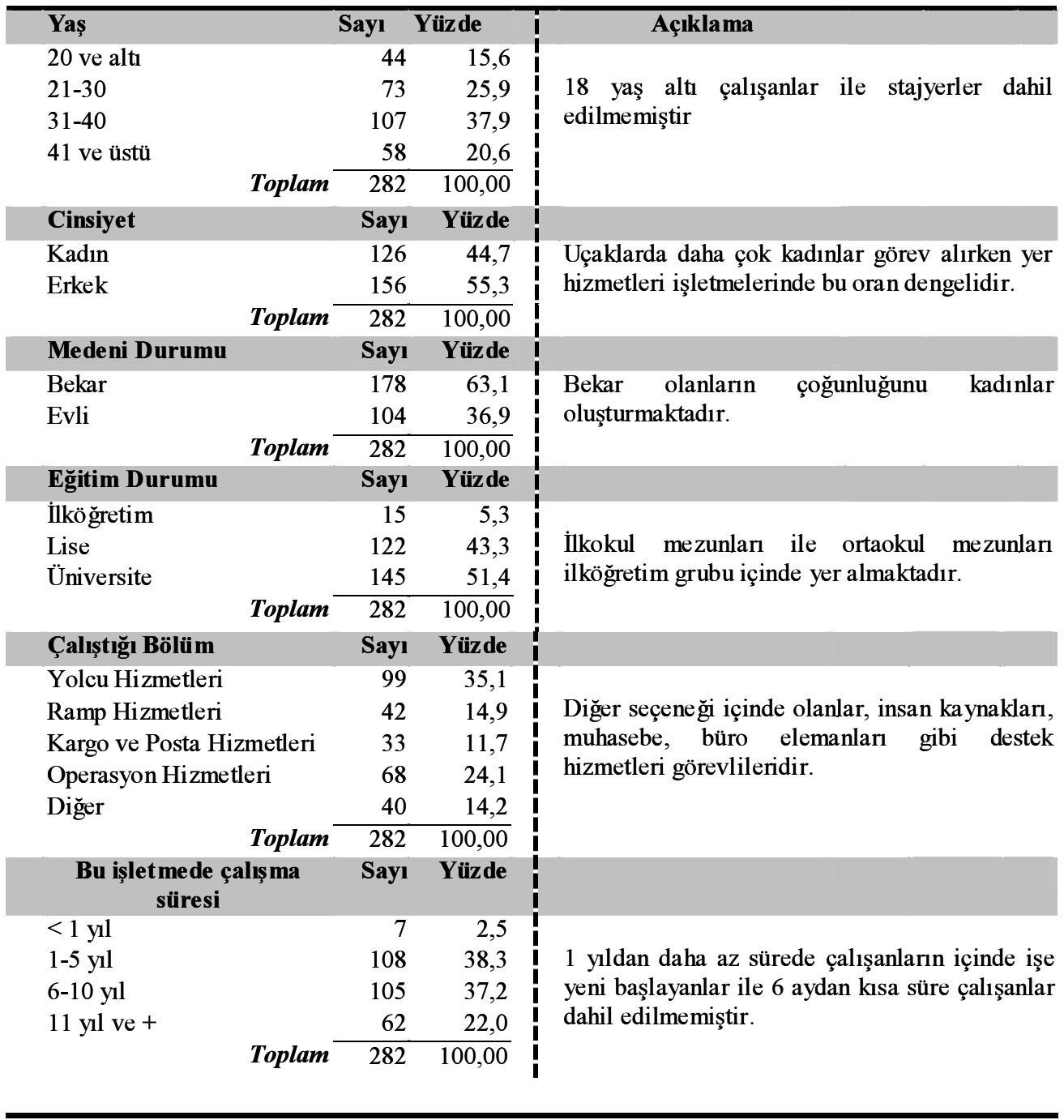


venilirlik ve geçerlilik analizlerini de içeren açıklayıcı faktör analizi (AFA) yapılmıştır. Sonraki aşamada araştırma kapsamında oluşturulan hipotezlerin ölçülmesi amacıyla Yapısal Eşitlik Modellemesinde korelasyon, yol grafiği ve katsayısı, uyum endeksleri ve model için ölçüm değerleri çıkarılmıştır.

\subsubsection{Sayısal ve Yüzdesel Dağılım}

Katılımcıların demografik özelliklerini açıklamak amaciyla oluşturulan tabloda (Tablo 1) yer alan sayısal ve yüzdesel dağ1lımlar SPSS 14.0 istatistik programı ile analiz edilmiştir. Çalışmada, anket yapılan iki havalimanında yer hizmetleri işletmelerinde çalışan sözleşmeli işgören sayısının (yarı zamanlı ve stajyer ögrrenciler hariç) toplam 388 olduğu belirlenmiştir. Üst ve ara kademe yöneticileri hariç, tüm işgörenlere yönelik hazirlanan anketlerin 282'si değerlendirmeye alınmıştır. Çalışanların bir kısmı katılmak istememiş ve yönetici konumunda olup da anketi cevaplayanlar da kapsam dişında tutulmuştur. Ana kütleye göre anketlerin değerlendirilme oranı \%73'dür.

Katılımcıların yaş gruplarına ilişkin bulgular incelendiğinde yaklaş1k \%80'inin 40 yaş altında olduğu görülmektedir. Bu durum sivil havacılık sektöründe daha dinamik işgörenlerin istihdam edildiğini göstermektedir. İşörenlerin \%55,3'ünün erkek ve \%63,1'inin bekar olması bu bulguyu desteklemektedir. Mevcut çalışanların yarısından fazlası üniversite mezunudur $(\% 51,4)$. Toplam çalışanların yaklaşık \%60'ı halen bulundukları işletmelerde 5 yıldan fazla süre görev yapmaktadır.

Çalışmada çıkarımsal istatistik analizi kapsamında öncelikle kullanılan ölçeklere ilişkin güvenilirlik ve geçerlilik analiz yapılmiştır. Örgütsel destek ölçeğinin güvenilirliği (Cronbach alpha) 0,83 ve geçerliliği $\mathrm{p}=, 001$ düzeyinde anlamlı olarak gerçekleşmiştir. Dört grupta toplanan değişkenleri oluşturduğu faktör değerleri Tablo 2'de yer almakta olup bu ölçeği oluşturan değişkenlerin OD'yi \%73 oranında açıkladığı görülmektedir.

Örgütsel bağlılık ölçeğinin güvenilirliği (Cronbach alpha) 0,86 ve geçerliliği $p=, 001$ düzeyinde anlamlı olarak gerçekleşmiştir. Üç grupta toplanan değişkenleri oluşturduğu faktör değerleri Tablo 3'de yer almakta olup bu ölçeği oluşturan değişkenlerin $\mathrm{OB}^{\prime}$ yi \%81

\section{Tablo 2}

Örgütsel Destek Ölçeğine İlişkin Faktör Analizi

\begin{tabular}{|c|c|c|c|c|c|c|c|}
\hline & FY & $\ddot{O Z D}$ & $T F Y$ & ORT & $\mathbf{F}$ & $a$ & $p$ \\
\hline 1.FAKTÖR : ÖZERKLIK & & 4,213 & 23,666 & 3,99 & 32,117 & 93 & 001 \\
\hline Karar verebilme yetkisi & ,914 & & & & & & \\
\hline Çalıșma programı mı düzenleyebilme & ,892 & & & & & & \\
\hline Çalıșma gruplanı olușturabilme & ,805 & & & & & & \\
\hline 2. FAKTÖR : KIȘISEL GELIȘIM & & 3,722 & 19,341 & 3,85 & 25,004 & ,87 &, 001 \\
\hline İșbașı eğitim & ,889 & & & & & & \\
\hline Sertifika programı &, 822 & & & & & & \\
\hline Tayin olanaklan & ,798 & & & & & & \\
\hline 3. FAKTÖR : TEŞVİKLER & & 2,926 & 17,011 & 3,72 & 19,919 &, 81 &, 004 \\
\hline Terfi olanaklan &, 825 & & & & & & \\
\hline Prim ve ödüller &, 801 & & & & & & \\
\hline Yönetime katılma & ,712 & & & & & & \\
\hline 4. FAKTÖR : SOSYAL GÜVENCE & & 1,241 & 13,002 & 3,71 & 8,229 & ,83 &, 002 \\
\hline İş sözleşmeleri & ,805 & & & & & & \\
\hline Kadroya geçme olanaklanı & ,727 & & & & & & \\
\hline
\end{tabular}

Kaiser-Meyer-Olkin Ölçümü=0,712 ve p<,001; Toplam farkın açıklanma oranı \% 73,020 
oranında açıkladığ1 görülmektedir.

Verilerin, tüm değişkenlerin yer aldığ 1 genel olarak güvenilirlik ve geçerlilik analizi de yapılmıştır. Genel güvenilirlilik (Cronbach alpha) 0,86; istatistiksel ölçümlerinin $\mathrm{F}=36,54$ ve $\mathrm{p}=, 001$ anlamlı olarak gerçekleşmiştir. Çalışmanın güvenilirlik düzeyinin yüksek olması (Sekaran, 2000:308; Özdamar, 1999:522) aynı zamanda diğer analizlerin yap1labileceğini göstermektedir. Verilere uygulanan temel bileşenler (Principal Component) analizinde, döndürme (Varimax) seçeneği kullanılmış olup faktör yük- leri 0,30 'dan az olan değişkenlere yer verilmemiştir. Çalışmada 5 faktör grubu içindeki değişkenler genel yapıyı 0,75 oranında açıklamaktadır. Bu faktörler arasındaki ilişkiler öngörülerek oluşturulan hipotezlerin ölçülmesi için doğrulayıcı faktör analizi (DFA) yapılmıştır. DFA'nın yapılmasında LISREL 8.80 istatistik paket programı kullanılmıştır. DFA'da öncelikle korelasyon analizi yapılmiş ve sonuçlar incelendiğinde faktörler arasında belirli bir ilişkinin olduğu görülmektedir.

Korelasyon analizi tablosunda görüldüğü

Tablo 3

Örgütsel Bağl1lık Ölçeğine İlişkin Faktör Analizi

\begin{tabular}{|c|c|c|c|c|c|c|c|}
\hline & $F Y$ & ÖZD & TFY & ORT & $\mathbf{F}$ & $a$ & $p$ \\
\hline 1.FAKTÖR : DEVAM BAĞLILIĞI & & 3,457 & 38,416 & 3,78 & 29,311 & 93 &, 001 \\
\hline Zorunluluk & ,944 & & & & & & \\
\hline Ekonomik çıkarlar & ,932 & & & & & & \\
\hline Daha iyi seçenek olmaması & 874 & & & & & & \\
\hline $\begin{array}{l}\text { 2. FAKTÖR : DUYGUSAL } \\
\text { BAĞLILIK }\end{array}$ & & 2,233 & 24,807 & 3,68 & 26,527 & ,80 & ,001 \\
\hline Örgüte ait olma duygusu & ,926 & & & & & & \\
\hline Kişisel bağlanma & 856 & & & & & & \\
\hline Mutlu olma & 824 & & & & & & \\
\hline $\begin{array}{l}\text { 3. FAKTÖR : NORMATİF } \\
\text { BAĞLILIK }\end{array}$ & & 1,599 & 17,761 & 3,22 & 12,500 & ,85 &, 001 \\
\hline Vicdani sorumluluk & ,916 & & & & & & \\
\hline Etik değerler & 857 & & & & & & \\
\hline Sadakat duygusu & 838 & & & & & & \\
\hline
\end{tabular}

Kaiser-Meyer-Olkin Ölçümü=0,719 ve $p<, 001$; Toplam farkn açıllanma oranı \%80,984

\section{Tablo 4}

Faktörlere İlişkin Korelasyon Analizi Sonuçları

\begin{tabular}{lccccccc}
\hline Değişkenler & N & Ort. & SS & 1 & 2 & 3 & $\mathbf{4}$ \\
\hline 1-OD & 282 & 3,74 & 1,06 & & & & \\
2-DEVB & 282 & 4,75 & 0,59 & $0,692^{*}$ & & & \\
3- DUYB & 282 & 4,53 & 0,93 & $0,706^{*}$ & $0,513^{*}$ & & \\
4- NORB & 282 & 3,32 & 1,03 & $0,632^{* *}$ & $0,546^{*}$ & $0,509 *$ & \\
5-IAE & 282 & 2,12 & 1,78 & $-0,692^{*}$ & $-0,662^{*}$ & $-0,734^{*}$ & $-0,404^{*}$ \\
\hline & ${ }^{*} \mathrm{p}<, 001$ & $* * \mathrm{p}<, 01$ & & & & &
\end{tabular}


gibi OD ile OB faktörleri arasında pozitif ve anlamlı bir ilişki bulunmaktadır. Bu ilişki düzeyleri, OD-DEVB $(\mathrm{r}=0,692)$ arasında önemli bir etkileşimin olduğunu göstermektedir. Aynı şekilde OD-DUYB $(r=0,706)$ ve OD-NORB $(\mathrm{r}=0,632)$ ilişkilerinin de önemli düzeyde olduğu görülmektedir. Diğger yandan OB faktörlerinin birbirleriyle olan ilişkileri de pozitif doğrusal yönde, anlamlı ve önemli düzeydedir. Buna karşın, $O D$ ve $O B$ faktörlerinin İAE ile olan ilişkisinin anlamlı ve önemli düzeyde gerçekleştiği görülürken ilişkinin yönü negatiftir. Korelasyon analizinde faktörler arasında en güçlü pozitif ilişki OD-DUYB $(\mathrm{r}=0,706)$ arasında iken negatif ilişki DUYB-İAE $(\mathrm{r}=-0,734)$ arasında gerçekleşmiştir.

Çalışmanın bu bölümünde yapısal eşitlik modeli (YEM) çerçevesinde oluşturulan yapıya göre bir DFA uygulanmıştır. Şekil 1'de oluşturulan modelde değişkenler arasındaki yol (path) tek yönlü oklar ile ifade edilmektedir. Her bir yolun katsayısı iki değişken arasındaki anlam düzeyini ortaya koymaktadır. DFA sonucunda faktörlerin, ilgili değişkenlerin üzerindeki standardize faktör yüklerinin 0.70 'den yüksek bir değer alması ve $t$ değerinin de anlamlı olması gerekir. Diğer yandan faktörlerin güvenilirlik katsayılarının 0,70'in üzerinde, faktörlerin açıklanan varyans tahmin değerlerinin de 0,50'nin üstünde olması beklenir. Ancak standardize faktör yüklerinin 0.50 'den yüksek olması genel olarak yapının uygun olduğunu gösterir (Comrey ve Lee, 1992).

DFA'da değişkenlerin standartlaştırılmış değerlerinin 0,50 'inin üzerinde ve yine tüm değişkenlerin $t>2$ değerlere sahip olması oluşturulan modelin doğru olduğunu göstermektedir. İçsel güvenilirliklerinin tüm faktörlerde 0,80 'in üzerinde, $\mathrm{p}<, 01$ olması ve $\mathrm{R}^{2}>0,50$ olarak gerçekleşmesi araştırma mo-

\section{Şekil 1}

Ölçme modeli standartlaştırılmış çözümleme değerleri

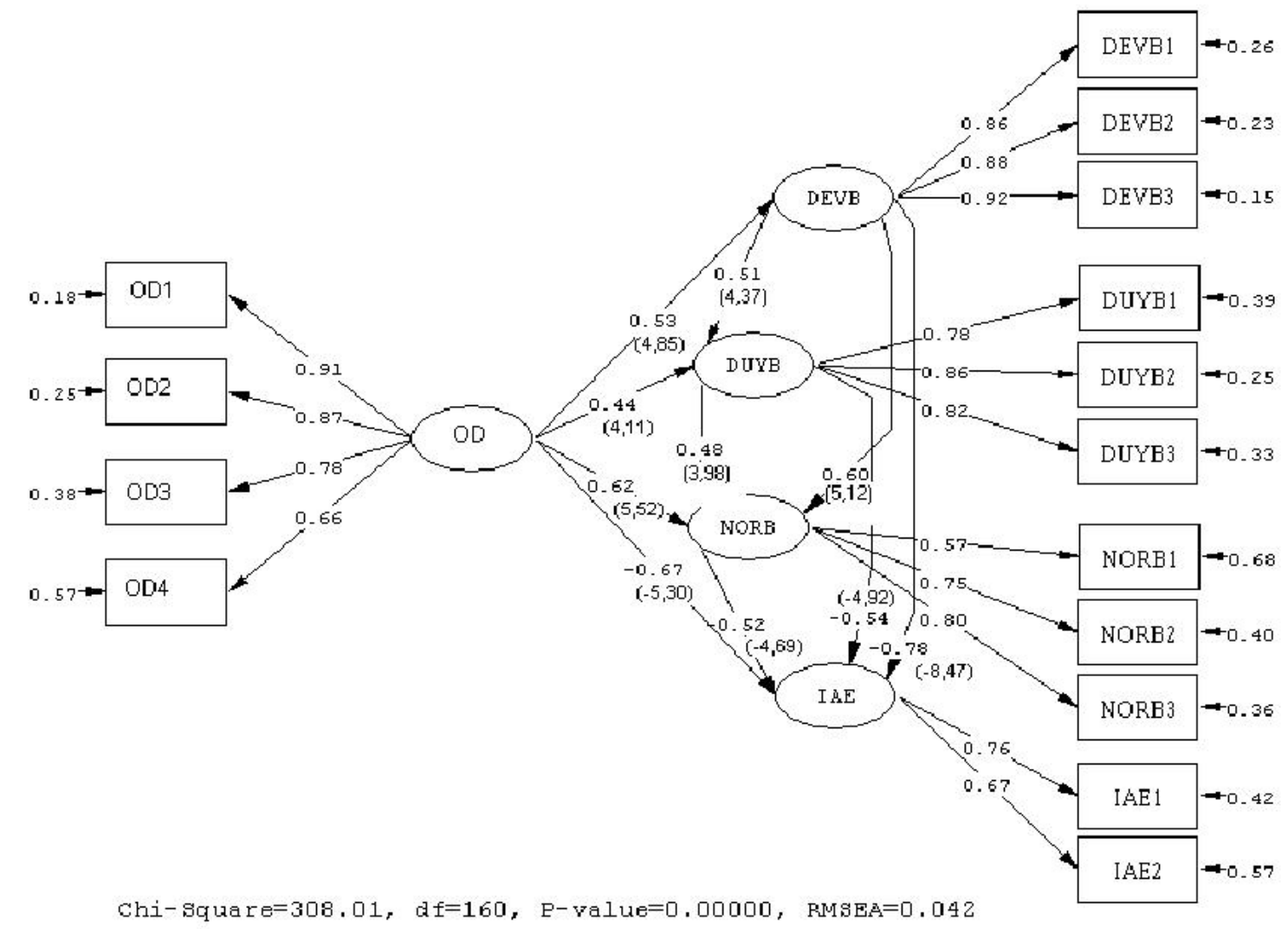


deli açısından ayrı bir önem taşımaktadır. Tablo 5'de yer alan değerler ölçme modelinin ilk aşamada uygun olduğunu göstermektedir. Ancak YEM'de ölçme modelinin genel yapı içinde bir bütün olarak kabul edilebilmesi, uyum iyiliği istatistiklerinin (Goodness-of-fit statistics) de istenen düzeyde olmasına bağlıdır (Şimşek, 2007:14). Model uygunluğunun değerlendirilmesinde kullanılan birbirinden farklı uyum endeksleri ve bu endekslerin sahip olduğu istatistiksel fonksiyonlar bulunmaktadır. Önerilen endeksler arasında en çok kullanılanlar olarak ki-kare istatistiği $\left(X^{2}\right)$, RMSEA (Ortalama hata karekök yaklaşımı-Root-Mean-Square Error Approximation), GFI (Uyum iyiliği endeksiGoodness-of-Fit Index) ve AGFI (Düzeltilmiş İyi Uyum Endeksi-Adjusted Goodness of Fit Index) gösterilmektedir (Joreskog ve diğ., 2001:154). DFA'da uyum endekslerinin 0,90'dan büyük olduğu görülmektedir. Çalışmada uyum endekslerinin olması gereken düzeyde gerçekleşmesi amacıyla örgütsel destek ve örgütsel bağl1lık faktörleri içinde toplam 13 değişken kapsam dişında tutulmuştur. Bu değişkenlerin bir kısmı veri tekrarı, bir kısmı da eksik veri nedeniyle model yapısını olumsuz etkilemiştir. Değişkenlerin kapsam dışında tutulması, uyum endekslerinin beklenen düzeyde gerçekleşmesi için başvurulan yöntemlerden birisidir.

Tablo 5'de yer alan sonuçlara göre, DFA'dan elde edilen veriler modelin uygun olduğu yönünde değerlendirilerek yapısal modelin analiz edilmesinin önünde engel olmadı ̆̆ını göstermektedir. RMSEA değerinin çok düşük çıkması, tutarlı ve geçerli bir model yapısına uygun ölçüm değerlerine ulaşıldığını göstermektedir. Nooteboom (2003:115), RMSEA değerinin 0,05'den küçük

Tablo 5

Araştırma modelinin ölçüm değerleri ve uyum ölçütleri

\begin{tabular}{|c|c|c|c|c|c|c|}
\hline $\begin{array}{c}\text { Gizil Değişkenler } \\
\text { (Faktörler) }\end{array}$ & $\begin{array}{c}\text { Gözlenen } \\
\text { Değişkenler }\end{array}$ & $\begin{array}{c}\text { Std. } \\
\text { Değerler }\end{array}$ & $\mathbf{t}$ & $\mathbf{R}^{2}$ & $\alpha$ & $p$ \\
\hline \multirow{4}{*}{$\begin{array}{c}\text { ORGÜTSEL } \\
\text { DESTEK(OD) }\end{array}$} & OD-1 & 0,91 & 5.63 & 0.82 & \multirow{4}{*}{$\mathbf{0 , 8 3}$} & \multirow{4}{*}{,001 } \\
\hline & OD-2 & 0,87 & 7.63 & 0.75 & & \\
\hline & OD-3 & 0,78 & 9.18 & 0.62 & & \\
\hline & OD-4 & 0,66 & 9.87 & 0.56 & & \\
\hline \multirow{3}{*}{$\begin{array}{l}\text { DEVAM } \\
\text { BAĞLILIĞI } \\
\text { (DEVB) }\end{array}$} & DEVB-1 & 0,86 & 9.24 & 0.74 & \multirow{3}{*}{$\mathbf{0 , 9 3}$} & \multirow{3}{*}{,001 } \\
\hline & DEVB-2 & 0,88 & 8.48 & 0.77 & & \\
\hline & DEVB-3 & 0,92 & 6.14 & 0.85 & & \\
\hline \multirow{3}{*}{$\begin{array}{l}\text { DUYGUSAL } \\
\text { BAĞLILIK } \\
\text { (DUYB) }\end{array}$} & DUYB-1 & 0,78 & 7.30 & 0.61 & \multirow{3}{*}{$\mathbf{0 , 8 0}$} & \multirow{3}{*}{,001 } \\
\hline & DUYB-2 & 0,86 & 8.56 & 0.75 & & \\
\hline & DUYB-3 & 0,82 & 8.31 & 0.67 & & \\
\hline \multirow{3}{*}{$\begin{array}{l}\text { NORMATIF } \\
\text { BAĞLILIK } \\
\text { (NORB) }\end{array}$} & NORB-1 & 0,57 & 9.11 & 0.52 & \multirow{3}{*}{$\mathbf{0 , 8 5}$} & \multirow{3}{*}{,001 } \\
\hline & NORB-2 & 0,75 & 9.01 & 0.64 & & \\
\hline & NORB-3 & 0,80 & 7.62 & 0.74 & & \\
\hline \multirow{2}{*}{$\begin{array}{l}\text { ISSTEN AYRILMA } \\
\text { EĞILIMİ (İAE) }\end{array}$} & İAE-1 & 0,76 & 8.34 & 0.73 & \multirow[b]{2}{*}{$\mathbf{0 , 8 7}$} & \multirow[b]{2}{*}{,008 } \\
\hline & İAE-2 & 0,67 & 9.76 & 0.62 & & \\
\hline $\begin{array}{c}\text { UYUM } \\
\text { ÖLÇÜTLERİ }\end{array}$ & \multicolumn{6}{|c|}{ 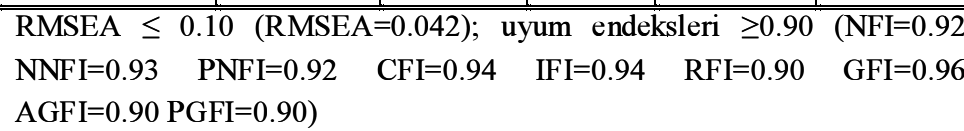 } \\
\hline
\end{tabular}


olmasını çok iyi bir uyum göstergesi olarak değerlendirmektedir. Yapısal modelde değişkenler içsel ve dişsal olmak üzere iki gruba ayrılmakta ve modeldeki değişkenlerin içsel-dışsal ayırımı araştırmacının deneyim, bilgi ve kuramsal araştırmasından elde ettiği verilere göre belirlenmektedir. Yapısal model şeklinde de görüldüğü gibi dışsal değişkenlerin oluşturduğu faktör OD olarak yer alırken içsel değişkenleri temsil eden faktör grupları DEVB, NORB, DUYB ve İAE şeklinde belirlenmiştir. Faktörlerin birbiriyle olan ilişkilerinin ölçülmesi amacıyla oluşturulan hipotezler istatistiksel olarak elde edilen bulgularla her biri ayrı ayrı olarak değerlendirmektedir.

H1: Algilanan örgütsel destek ile devam bağlılı düzeyi arasında anlamlı bir ilişki vardır.

OD işgörenlerin örgüte olan bağl1lıklarını güçlendiren bir yaklaşım olarak önemli sonuçlar çıkarmaktadır. Çalışma modelinde OD-DEVB yol kat sayisinin $(0,53)$ anlamlı $(\mathrm{p}<, 001)$ ve pozitif olması, bu iki faktör arasındaki ilişkinin önem düzeyi ve yönünü ortaya koymaktadır. Diğer yandan bu faktörler arasındaki ilişkide $t>2(t=4,85)$, ve $R^{2}=0,73$ olarak gerçekleşmiştir. Bu verilere göre örgüt içinde işgörenlere sağlanan destek unsurlarının örgüte devam bağlılığını arttırdığını söylemek mümkündür. Elde edilen bulgular sonucunda $\mathrm{H} 1$ hipotezi kabul edilmektedir.

H2: Algilanan örgütsel destek ile duygusal bağhllık düzeyi arasında anlamlı bir ilişki vardır.

İşletmenin yönetim politikası ve denetim, iletişim, statü, çalışma koşulları, iş güvenliği, ücret vb. unsurları da içeren OD, işgörenin örgüt ile özdeşlemesinde etkili olabilmektedir. Bu çalışmada OD-DUYB ilişkisinin istatistiksel analiz sonuçları da bunu desteklemektedir. Bu iki faktör arasında yol katsayısı $(0,44)$ olarak pozitif yönlü gerçekleşmiş olup, $t>2(t=4,11)$, ve $R^{2}=0,68$ bulgularına göre anlamlı $(\mathrm{p}<, 01)$ bir ilişkinin olduğu görülmektedir. OD'nin DUYB'nin sağlanmasında önemli bir etkisinin olması, işgörenlerin kendilerine verilen değerin farkında olduğunu da göstermektedir. Bulgulara göre
$\mathrm{H} 2$ hipotezi kabul edilmektedir.

H3: Algilanan örgütsel destek ile normatif bağlılık düzeyi arasında anlamlı bir ilişki vardır.

Örgüt üyesi olarak kalmanın vicdani bir yükümlülük olduğunu ifade eden NORB, OD'den olumlu yönde etkilenmektedir. ODNORB ilişkisinin pozitif doğrusal yönde $(0,62)$, anlamlı $(p<, 001)$ ve önemli düzeydedir. Bu iki faktör arasındaki ilişkinin istatistiksel olarak önemli bulgulara $(t=5,52$ ve $\left.\mathrm{R}^{2}=0,66\right)$ sahip olması, yönetim tarafından sağlanan desteğin işgörenler açısından olumlu karşılandığını ve kendilerine değer verildiği yönünde algıladıkları sonucunu çıkarmaktadır. Bu değerlendirmeler ışığında H3 hipotezi kabul edilmektedir.

H4: Algılanan örgütsel destek ile işgörenlerin işten ayrilma eğilimi arasında anlamlı bir ilişki vardir.

OD'nin eksikliği ya da yokluğunda oluşabilen ilgisizlik, belirsizlik, iş güvencesinin olmaması gibi durumlar, aynı zamanda işgörenlerin önemsenmediği duygusuna neden olabilmektedir. Buna bağl1 olarak oluşacak iş doyumsuzluğu işgörenlerin İAE'nin artmasinda etkili olabilmektedir. OD-İAE ilişkisindeki etkileşimin negatif $(-0,67)$ doğrusal yönde, anlamlı $(\mathrm{p}<, 001), \mathrm{t}>2(\mathrm{t}=-5,30)$ ve $\mathrm{R}^{2}=0,68$ gerçekleşmiş olması OD'nin İAE üzerinde etkili olduğunu göstermektedir. Diğer bir deyişle OD'nin eksikliği ya da yokluğunun sonucunda İAE artmaktadır. ODİAE ilişkisi üzerine oluşturulan $\mathrm{H} 4$ hipotezi kabul edilmektedir.

H5: İsgörenlerin devam bağlllık düzeyi ile işten ayrılma eğilimi arasında anlamlı bir ilişki vardir.

DEVB-İAE ilişkisinde korelasyon analizi sonuçlarına göre önemli $(r=-0,662)$ ve anlamlı $(\mathrm{p}<, 001)$ bir ilişkinin olduğu ortaya çımıştır. Aynı şekilde iki faktör arasındaki yol katsayısı $(-0,78), \mathrm{t}=-8,47$ olarak gerçekleşmiş olup ilişki düzeyinin güçlü $\left(\mathrm{R}^{2}=0,73\right)$ olması etkileşimin derecesini göstermektedir. DEVB-İAE ilişkisinin negatif yönlü olması, örgütsel bağlilığın devam boyutunu oluştu- 
ran unsurların oluşmaması durumunda İAE'nin artacağını göstermektedir. İşgörenin örgütsel düzeyde katkılarının azalması ya da başka iş seçeneklerinin artması DEVB'nin azalmasına neden olurken İAE'yi de arttırmaktadır. Diğer bir deyişle işgörenin örgüte olan DEVB arttığı zaman İAE düşmektedir. Bu durumda DEVB-İAE ilişkisini ifade eden H5 hipotezi kabul edilmektedir.

H6: İşgörenlerin duygusal bağlılık düzeyi ile işten ayrulma eğilimi arasında anlamlı bir ilişki vardir.

DUYB-İAE arasinda önemli düzeyde negatif yönlü $(r=-0,734)$ ve anlaml $(p<, 001)$ bir ilişki söz konusudur. Bu ilişkide faktörler arasındaki standartlaştırılmış değer $(-0,54), \mathrm{t}=$ $-4,92$ ve $\mathrm{R}^{2}=0,62$ olarak gerçekleşmiştir. İşgörenin örgütle özdeşleşmesi ve olumlu bir etkileşim halinde olması DUYB'nin artmasına neden olurken buna karşın İAE'nin de azalmasını sağlamaktadır. İşgörenlerin büyük ölçüde yaşanan iş deneyimleri sonucunda gelişen DUYB, örgütü kendine yakın hissetmesine ve sorumluluklarını yerine getirmesine yöneltmektedir. Bu durumun oluşmaması halinde İAE artmakta ve ters yönlü ilişkinin oluşmasına neden olmaktadır. Bu sonuca göre H6 hipotezi kabul edilmektedir.

H7: İsgörenlerin normatif bağlllık düzeyi ile işten ayrılma eğilimi arasında anlamlı bir ilişki vardir.

Diğer yandan NORB-İAE arasında da negatif doğrusal bir ilişki vardır. Ölçüm değerleri diğer içsel değişkenlere göre biraz düşük olarak gerçekleşse de NORB-İAE arasında negatif yönlü $(\mathrm{r}=-0,404)$ ve anlamlı $(\mathrm{p}<, 001)$ bir ilişkinin olduğu standartlaştırılmış değer $(-0,52)$ ve $t=-4,89$ değerlerinden de anlaşılmaktadır. Bu bulgulara göre H7 hipotezi kabul edilmektedir. Buradan hareketle, işgörenlerin sosyal ve ekonomik çıkarları nedeniyle, vicdani yükümlülükleri ya da duygusal olarak kendini örgütün bir üyesi olarak görmemeleri sonucunda başka arayışlar içine girmelerinin İAE'yi arttırdığı söylenebilir.

\section{Tartışma Ve Sonuç}

Havalimanı yer hizmetleri işletmeleri, ulaştırma sektörü içinde kurumsal özellikleri nedeniyle daha düzenli örgüt yapısına sahiptir. Örgüt içinde görev, yetki ve sorumlulukların belirgin olması yönetim faaliyetlerini de olumlu yönde etkilemektedir. Yönetim-işgören ilişkilerinin örgütün amaçları ve gerekleri çerçevesinde geliştirilmesi örgütsel performansın arttırılmasına katkı sağlayabilmekte ve aynı zamanda kadrolama sürecinde verilecek kararları etkileyebilmektedir. Bu da sonuçta işgörenlerin örgüt içinde yer alıp almayacağını belirleyebilen unsurlardan birisi olarak değerlendirilmektedir.

Çalışmada öncelikle dişsal faktör olarak örgütsel destek belirlenmiş ve içsel değişkenlerin oluşturduğu faktör grupları ile ilişkileri incelenmiştir. İstatistiksel olarak elde edilen bulguların sonucunda örgütsel desteğin örgütsel bağlılık faktör grupları (DEVB, DUYB, NORB) ile pozitif bir ilişki içinde olduğu buna karşın işten ayrılma eğilimi ile negatif bir ilişkide olduğu ortaya konulmuştur. Örgütsel bağlılık faktörlerinin oluşturulmasinda örgütsel desteğin önemli bir etkisinin olduğu sonucuna ulaşılırken bu kapsamda oluşturulan hipotezler kabul edilmiştir. Diğer bir deyişle, örgütsel destek kapsaminda sağlanan özerklik, kişisel gelişim olanakları, çeşitli teşvikler (ödül, prim, terfi vb) ve sosyal güvencenin, işgörenlerin duygusal, devam ve normatif bağlilıklarının arttırılmasında önemli bir destekleyici rolü olduğu belirlenmiştir. Ancak, destek unsurlarının yetersizliği veya yokluğunda işgörenlerin güdülenmesinin daha zor olması, iş doyumunun sağlanamaması ve buna bağlı olarak başka çalışma yerlerinin aranması işten ayrılma eğiliminin artmasına neden olmaktadir.

Çalışmada ulaşılan bir başka sonuçta örgütsel bağlılık faktörlerinin işten ayrılma eğilimi ile olan ilişkisine bağlı olarak ortaya konulmuştur. İşgörenlerin kendilerini örgüte ait hissetmemeleri, örgüt içi ilişkilerin zayıf olması, işgörenleri örgüte katkısının olmaması, örgüt kurallarının işgörenlere göre de- 
ğişmesi ya da farklı uygulanması bağlılık faktörlerinin oluşmasını engellemektedir. Bu bakımdan örgütsel bağlılık faktörlerinin zayıf olması işgörenlerin örgütle ilişkilerinde olumsuzlukların görülmesine neden olduğu için işten ayrılma eğiliminin artmasına yol açmaktadır. Bu faktörler baz alınarak oluşturulan hipotezlerin ölçülmesinde de istatistiksel olarak negatif yönlü ilişkilerin olduğu ve dolayısıyla tüm hipotezlerin kabul edildiği görülmektedir.

Gerek örgütsel destek - işten ayrılma eğilimi ilişkisi, gerekse örgütsel bağlılık faktörlerinin işten ayrılma eğilimi ile olan ilişkisinde ortaya çıkan negatif yönlü ilişki, dişsal ve içsel faktörlerin işten ayrılma eğilimini olumsuz olarak etkilediği anlamını taşımamaktadır. İstatistiksel olarak negatif çıkan bu sonuçların faktörler arasındaki ilişkide olumlu anlam taşıdığı bir gerçektir. Diğer bir deyişle, örgütsel destek unsurlar1nın artması veya örgütsel bağlılığın sağlanması sonucunda işten ayrılma eğiliminin azalması, bu faktörlerin işten ayrılma eğilimi üzerinde olumlu etki yaparak işgörenlerin işte kalmalarını sağlamaktadır.

Literatürde yer alan bazı çalışmalarla (örn. Erkutlu ve Chafra, 2006; Cho ve Johanson, 2008; Yang 2010; Özdevecioğlu, 2003) benzerlik gösterse de, bu çalışmanın havalimanında yapılması nedeniyle farklı yönleri de bulunmaktadır. Öncelikle havalimanı yer hizmetleri işletmelerinin özellikleri nedeniyle işgörenlerin örgütsel destek algılamaları diğer turizm işletmelerindeki işgörenlere göre daha yüksek olarak gerçekleşmiştir (Örn. Yang, 2010; Ferris ve diğ., 2009; Susskind ve diğ., 2007). Turizm sektöründe farklı hizmet sunan işletmeleri arasında örgütsel bağılılık ile ilgili bir karşılaştırma yapmak mümkün olamamaktadır. Bunun iki nedeni vardır; birincisi işletmelerin farklı özellik taşıması nedeniyle işgören nitelikleri de farkl1dır. İkincisi, turizm sektörü içinde en yüksek işgören devir oranı yiyecek içecek işletmeleri, konaklama işletmeleri, seyahat acenteleri şeklinde sıralanırken (Tütüncü ve Demir, 2003), en düşük oran yer hizmetleri işletmelerinde görülmektedir. Dolayısıyla başka et- kenlerinde rol aldığ 1 işten ayrılma eğiliminin yalnızca örgütsel destek ile ilişkilendirilemeyeceği ve örgütsel bağl1lı̆̆ın mevsimlik işletmelerde söz konusu olamayacağı için karşılaştırma yapmak doğru olmayacaktır.

Sonuçta işgörenleri güdüleyici özellikteki destek faktörleri örgütsel düzeyde bağlılığın oluşmasında olumlu katkılar yaparken buna bağlı olarak işten ayrılma eğilimi de azalmaktadır. Aynı şekilde DEVB, DUYB ve NORB'nin sağlanması da işten ayrılma eğiliminin azalmasında etkili olmaktadır. Çalışmada ulaşılan sonuçlar özellikle yer hizmetleri işletmeleri açısından değerlendirilmelidir. Bu tür işletmelerin diğer hizmet işletmelerine göre daha yoğun ve dikkat gerektiren iş unsurlarına sahip olması, işgörenlerin belirli bir süre sonra örgütsel destek olanaklarının da yetersiz kalmasıyla başka arayışlara girmesine neden olmaktadır. $\mathrm{Bu}$ durumda örgütsel destek kadar örgütsel bağlılık yaratacak çalışmaların da yapılması gerekir.

Turizm sektörünün farklı hizmet dallarında faaliyet gösteren işletmelerin yapısal özellikleri nedeniyle insan kaynaklarının nitelikleri, çalışma koşulları, çalışma süreleri, işin yapısı vb. durumlar da farklıdır. Bu alanda yapılan çalışmalarında daha çok konaklama işletmelerinde uygulama alanı bulduğu bir gerçektir. Ulaştırma ve seyahat sektöründe daha sınırlı olan çalışmaların arttırılması gerekir. Gelecekte turizm sektörünün tüm hizmet alanlarında örgütsel davranış konuları kapsamında çalışmaların yapılarak bulgu ve sonuçların karşılaştırılması gerek turizm işletmeleri, gerekse araştırmacılar açısından önemli bir kaynak teşkil edebilecektir. 


\section{Kaynakça}

Allen N.J. ve Meyer J.P. (1990). The Measurement and Antecedents of Affective, Continuance and Normative Commitment to the Organization, Journal of Occupational and Organizational Psychology, 63(1): 1-8.

Armstrong, M. (2006). Handbook of Human Resource Management Practice. London: Kogan Page.

Bredin, K. ve Söderlund, J. (2007). Reconceptualising Line Management in ProjectBased Organisations, Personnel Review, 36(5): 818-833.

Camp, S.D. (1992). Assessing the Effects of Organizational Commitment and Job Satisfaction On Turnover: An Event History Approach, The Prison Journal, 74(3): 279-305.

Chen, Z.X. ve Francesco, A.M. (2003). The Relationship between the Three Components of Commitment and Employee Performance in China, Journal of Vocational Behavior, 62(3): 490-516.

Cho, S. ve Johanson, M.M. (2008). Organizational Citizenship Behavior and Employee Performance: A Moderating Effect of Work Status in Restaurant Employees, Journal of Hospitality \& Tourism Research, 32(3): 307-326.

Clugston, M. (2000). The Mediating Effects of Multidimensional Commitment on Job Satisfaction and Intend to Leave, Journal of Organizational Behavior, 21(4): 477486.

Comrey, A.L. ve Lee, H.B. (1992). A First Course in Factor Analysis. New Jersey: Lawrence Erlbaum Associates Inc.

Decotiis, T.A. ve Summers, T.P. (1987). A Path Analysis of a Model of the Antecedents and Consequences of Organizational Commitment, Human Relations, 40: 445-470.
Demir, M. (2010). Duygusal Zekanın İnsan Kaynakları Seçimindeki Etkisi: Konaklama İşletmelerinde Yöneticiler Üzerine Bir Araştırma, Uluslararası İnsan Bilimleri Dergisi, 7(1): 1066-1081.

Eisenberger, R. ve Diğ. (2002). Perceived Supervisor Support: Contributions to Perceived Organizational Support and Employee Retention, Journal of Applied Psychology, 87(3): 565-573.

Eisenberger, R. ve Diğ. (1990). Perceived Organizational Support and Employee Diligence, Commitment, and Innovation, Journal of Applied Psychology, 75(1): 51-59.

Erkutlu, H.V. ve Chafra, J. (2006). Relationship between Leadership Power Bases and Job Stress of Subordinates: Example from Boutique Hotels, Management Research News, 29(5): 285-297.

Ferris, D.L. ve Diğ. (2009). Organizational Supports and Organizational Deviance: The Mediating Role of Organizationbased Self-esteem, Organizational Behavior and Human Decision Processes, 108(2): 279-286.

Fuller, J.B. ve Diğ. (2003). A Social Identity Perspective on the Relationship between Perceived Organizational Support and Organizational Commitment, Journal of Social Psychology 143(6): 789-791.

Guadagnoli, E. ve Velicer, W. F. (1988). Relations of Sample Size to the Stability of Component Patterns, Psychological Bulletin, 103: 265-275.

Hunt, S.D. ve Diğg. (1989). Corporate Ethical Values and Organizational Commitment in Marketing, Journal of Marketing, 53(3): 79-90.

Huselid, M.A. ve Day, N.E. (1991). Organizational Commitment, Job Involvement and Turnover: A Substantive and Methodological Analysis, Journal of Applied Psychology, 76(3): 380-391. 
Joreskog, K. ve Diğ. (2001). LISREL 8: User's Reference Guide. Uppsala: Scientific Software International Inc.

Kondratuk, T.B. ve Diğ. (2004). Linking Career Mobility with Corporate Loyalty: How Does Job Change Relate to Organizational Commitment. Journal of Vocational Behavior, 65(2): 332-349.

Lamsa, A.M. ve Savolanien, T. (2000). The Nature Of Managerial Commitment To Strategic Change, Leadership \& Organization Development Journal, 21 (6): 297-306.

Lew, T.Y. (2009). The Relationships between Perceived Organizational Support, Felt Obligation, Affective Organizational Commitment and Turnover Intention of Academics Working with Private Higher Educational Institutions in Malaysia, European Journal of Social Sciences, 9(1): 72-87.

Meyer, J.P. ve Allen, N.J. (1991). A ThreeComponent Conceptualization of Organizational Commitment, Human Resources Management Review, 91(1): 61-89.

Meyer, J.P. ve Allen, N.J. (1997). Commitment in the Workplace, Theory, Research and Application. London: Sage Publications.

Meyer, J.P. ve Smith, C.A. (2000). HRM Practices and Organizational Commitment: Test of a Mediation Model, Canadian Journal of Administrative Sciences, 17(4): 319-331.

Meyer, J.P. ve Diğ.. (1993). Commitment to Organizations and Occupations: Extension and Test of a Three-Component Conceptualization, Journal of Applied Psychology, 78(4): 538-551.

Meyer, J.P. ve Diğ. (2002). Affective, Continuance, and Normative Commitment to the Organization: A Meta-analysis of Antecedents, Correlates, and Consequences, Journal of Vocational Behavior, 61(1): 20-52.
Mowday, R.T. ve Diğ. (1979). The Measurement of Organizational Commitment, Journal of Vocational Behavior, 14 (2): 224-247.

Namasivayam, K. ve Zhao, X. (2007). An Investigation of the Moderating Effects of Organizational Commitment on the Relationships between Work-Family Conflict and Job Satisfaction among Hospitality Employees in India, Tourism Management, 28(5): 1212-1223.

O'Neill, J.W. ve Diğ. (2009). Work-Family Climate, Organizational Commitment, and Turnover: Multilevel Contagion Effects of Leaders. Journal of Vocational Behavior, 74(1): 18-29.

Obeng, K. ve Ugboro, I. (2003). Organizational Commitment among Public Transit Employees: An Assessment Study, Journal of the Transportation Research Forum, 57(2): 83-98.

Øgaarda, T. ve Diğ. (2008). Perceptions of Organizational Structure in the Hospitality Industry: Consequences for Commitment, Job Satisfaction and Perceived Performance, Tourism Management, 29(4): 661-671.

Özdamar, K. (1999). Paket Programlar ile İstatistiksel Veri Analizi. Eskişehir: Kaan Kitabevi

Özdevecioğlu, M. (2003). Alg1lanan Örgütsel Destek ile Örgütsel Bağlılık Arasındaki İlişkilerin Belirlenmesine Yönelik Bir Araştırma, D.E.Ü. İ.İ.B.F. Dergisi, 18(2): 113-130.

Paulin, M. ve Diğ. (2006), Service Climate and Organizational Commitment: the Importance of Customer Linkages, Journal of Business Research, 59(8): 906-915.

Payne, S.C. ve Huffman, A.H. (2005). A Longitudinal Examination Of The Influence Of Mentoring On Organizational Commitment And Turnover, Academy of Management Journal, 48(1): 158-168. 
Rhoades, L. ve Eisenberger, R. (2002). Perceived Organizational Support: A Review of the Literature, Journal of Applied Psychology, 87(4): 698-714.

Schwepker, C.H. (2001). Ethical Climate's Relationship to Job Satisfaction, Organizational Commitment, and Turnover Intention in the Salesforce, Journal of Business Research, 54(1): 39-52.

Sekaran, U. (2000). Research Methods for Business: A Skill Building Approach, New York: John Wiley \& Sons, Inc.

Shore, L.M. ve Tetrick, L.E. (1991). A Construct Validity Study of the Survey of Perceived Organizational Support, Journal of Applied Psychology, 76(5): 637-643.

Shore, L.M. ve Wayne, S.J. (1993). Commitment and Employee Behavior: Comparison of Affective Commitment and Continuance Commitment with Perceived Organizational Support, Journal of Applied Psychology 78(5): 774-780.

Şimşek, Ö.F. (2007). Yapısal Eşitlik Modellemesine Giriş: Temel İlkeler ve LISREL Uygulamaları. Ankara: Ekinoks Yayınevi.

Somers, M., ve Birnbaum, D. (2000). Exploring the Relationship between Commitment Profiles and Work Attitudes, Employee Withdrawal, and Job Performance, Employees-Attitudes, Public Personel Management, 29 (3): 353-365.

Susskind, A.M. ve Diğ. ( 2007). How Organizational Standards and Coworker Support Improve Restaurant Service, Cornell Hotel and Restaurant Administration Quarterly 48(4): 370-379.

Tütüncü, Ö. ve Demir, M. (2003). “Konaklama İşletmelerinde İnsan Kaynakları Kapsamında İşgücü Devir Hızının Analizi ve Muğla Bölgesi Örneği", DEÜ SBE Dergisi, 5, (2), 146-169.
Tütüncü, Ö. ve Küçükusta, D. (2007). Relationship between Organizational Commitment and EFQM Business Excellence Model: A Study on Turkish Quality Award Winners, Total Quality Management, 18 (10): 1083-1096.

Ugboro, I.O. ve Obeng, K. (2000). Top Management Leadership, Employee Empowerment, Job Satisfaction, and Customer Satisfaction in TQM Organizations: An Empirical Study, Journal of Quality Management, 5: 247-272.

Valentine, S. ve Diğ. (2002). Ethical Context, Organizational Commitment, and Person-Organization Fit, Journal of Business Ethics, 41(4): 349-360.

Van Knippenberg, D. ve Sleebos, E. (2006). Organizational Identification versus Organizational Commitment: Self-Definition, Social Exchange, and Job Attitudes, Journal of Organizational Behavior, 27:571-584

Van Scotter, J.R. (2000). Relationships of Task Performance and Contextual Performance with Turnover, Job Satisfaction, and Affective Commitment, Human Resource Management Review, 10 (1): 79-95.

Wayne, S.J. ve Diğ. (2002). The Role of Fair Treatment and Rewards in Perceptions of Organizational Support and LeaderMember Exchange, Journal of Applied Psychology, 87(3): 590-598.

Wayne, S.J. ve Diğ. (1997). Perceived Organizational Support and Leader-Member Exchange: A Social Exchange Perspective, Academy of Management Journal, 40(1): 82-111.

Whittaker, S. ve Marchington, M. (2003). Devolving HR Responsibility to the Line Threat, Opportunity or Partnership?, Employee Relations, 25(3): 245-261.

Yang, T.J. (2010) Antecedents and Consequences of Job Satisfaction in the Hotel Industry, International Journal of Hospitality Management, 29(4): 609-619. 